\title{
LETTER
}

\section{Evidence for collective medication in ants}

Philippe Christe ${ }^{1}$, Anne

Oppliger $^{1,2}$, Francesco Bancalà ${ }^{1}$, Grégoire Castella ${ }^{1}$, Michel Chapuisat $^{1}$ *

${ }^{1}$ Institute of Ecology, Laboratory of Zoology and Animal Ecology, Biology Building, University of Lausanne, 1015 Lausanne, Switzerland

${ }^{2}$ Institute of Occupational Health Sciences, Bugnon 19, 1005 Lausanne, Switzerland *Correspondence: E-mail: michel.chapuisat@ie-zea.unil.ch

\begin{abstract}
Social organisms are exposed to many pathogens, and have evolved various defence mechanisms to limit the cost of parasitism. Here we report the first evidence that ants use plant compounds as a collective mean of defence against microorganisms. The wood ants Formica paralugubris often incorporate large quantities of solidified conifer resin into their nests. By creating resin-free and resin-rich experimental nests, we demonstrate that this resin inhibits the growth of microorganisms in a context mimicking natural conditions. Such a collective medication probably confers major ecological advantages, and may be an unrecognized yet common feature of large, complex and successful societies.
\end{abstract}

\section{Keywords}

Collective medication, Formica paralugubris, host defence, parasitism, resin, wood ants.

Ecology Letters (2003) 6: 19-22

\section{INTRODUCTION}

A major cost of social life is the increased exposure to pathogens (Møller et al. 1993; Schmid-Hempel 1998; Nunn et al. 2000; Tella 2002). This cost of sociality is expected to be particularly high for social insects, which live in crowded, persistent, warm and resource-rich nests providing ideal conditions for the development of microorganisms (Hölldobler \& Wilson 1990). Hence, social insects have evolved a variety of behavioural and physiological defence mechanisms, including antibiotic-producing symbionts (Currie et al. 1999), allogrooming (Rosengaus et al. 1998), antibiotic secretions (Rosengaus et al. 2000; Poulsen et al. 2002), removal of wastes and corpses (Hart \& Ratnieks 2001), and immune defences (Moret \& Schmid-Hempel 2000; Traniello et al. 2002). Another potential mechanism of defence may be to add plant compounds with antimicrobial properties to the nest.

Wood ants actively bring solidified resin to their nests, and this particular behaviour has intrigued naturalists since the eighteenth century (de Réaumur 1928). So far, the function of this resin remained speculative, and several nonmutually exclusive hypotheses have been suggested, including nutrition, protection against ultra-violet light, nest consolidation, or water repulsion (Gösswald 1989; Lenoir et al. 1999). Because conifer resin probably protects trees against invading bacteria and fungi (Cowan 1999), wood ants may also use resin as a means to suppress the activity of microorganisms in their mounds (Gösswald 1989; Lenoir et al. 1999). We tested this hypothesis experimentally by examining whether the presence of resin inhibits the growth of bacteria and fungi in wood ant nests. For this aim, we created resin-rich and resin-free experimental nest units with workers, and monitored the presence of bacteria and fungi.

\section{MATERIALS AND METHODS}

\section{Sampling}

The study population, located near the Chalet à Roch in the Swiss Jura mountains, consists of hundreds of large mounds forming a supercolony (Chapuisat et al. 1997). The density of nests is very high, each mound contains many philopatric queens, and neighbouring mounds are interconnected by trails (Chapuisat \& Keller 1999). In November 2001, 2 L of nest material and workers were collected from each of 20 randomly chosen nests along a $1-\mathrm{km}$ transect. The nest material was sampled from within the upper part of the mounds, and consisted of untransformed twigs and needles. All pieces of resin were removed, and the total amount of resin was weighed for each of those samples of nest material.

\section{Experimental nest units}

Nest material and workers from the 20 samples were completely mixed, taking advantage of the lack of aggression between workers of this population. The entire mix was subsequently split into 20 homogeneous experimental units. Each experimental unit consisted of $1.6 \mathrm{~L}$ of nest material, 
and approximately 600 workers were placed in large plastic containers side-coated with fluon to prevent ants from escaping. Eight grams of resin collected from ant nests were added to 10 of the experimental units, whereas the other 10 remained resin-free. Eight grams of resin correspond to approximately 160 pieces of resin. Nest material and resin are continuously mixed by the ants, thus ensuring a homogeneous distribution of resin. Experimental units were kept at $27{ }^{\circ} \mathrm{C}$ with regular vaporization of sterile water to maintain high humidity, thus mimicking natural conditions. Ants were fed with $8 \%$ sugar solutions and distilled water. After 4 weeks, microbiological tests were conducted.

\section{Microbiological tests}

The concentration of microorganisms was assessed by diluting $0.1 \mathrm{~g}$ of randomly selected nest material (without resin) from each experimental unit into $5 \mathrm{~mL}$ of $0.1 \%$ peptone solution and plating dilutions of this solution onto three different nutritive media (Hurst et al. 1997): Tryptic Soy Agar (TSA), Eosin Methylene Blue agar (EMB) and Dichloran Glycerol 18 agar (DG18). TSA was supplemented with cycloheximide $\left(500 \mathrm{mg} \mathrm{L}^{-1}\right)$ to inhibit fungal growth. This medium is commonly used for cultivating many kinds of environmental bacteria. EMB is selective for gramnegative bacteria. DG18 is selective for xerophilic fungi. All plates were incubated at $27^{\circ} \mathrm{C}$. Bacterial colonies (TSA, EMB) were counted after $48 \mathrm{~h}$ of growth, and fungal colonies (DG18) after 5 days. The three most frequent bacterial species were isolated on the TSA medium and identified with the API system (API 20 NE, BioMérieux, France). Additionally, one of these bacterial species was isolated and plated on a standard medium for susceptibility testing of pathogens (Müller-Hinton Agar). Two pieces of resin were placed on the surface of the plate. One of these pieces had been previously sterilized under UV light, and the other was untreated. After $24 \mathrm{~h}$ at $35{ }^{\circ} \mathrm{C}$, the inhibition halos surrounding the resin were measured.

\section{RESULTS}

We found conifer (Picea abies) resin in every nest sampled. However, the quantity of resin varied greatly among nests (mean $=2.3 \mathrm{~g} / \mathrm{L}$ of nest material, $\mathrm{SE}=0.58$, range 0.03 $9.3 \mathrm{~g} \mathrm{~L}^{-1}, N=20$ ).

The presence of resin in the experimental units had a negative effect on the growth of microorganisms (Fig. 1). The number of colony-forming units was significantly lower in nests containing resin than in resin-free nests for bacteria and fungi (TSA: mean CFU $10^{-4} \mathrm{~g}^{-1} \pm \mathrm{SE}=27740 \pm$ 2370 without resin and $22140 \pm 1850$ with resin, one-tailed Mann-Whitney $U$-test $U=75, \quad P=0.027 ; \quad$ DG18: $319 \pm 126$ without resin and $90 \pm 59$ with resin, one-tailed

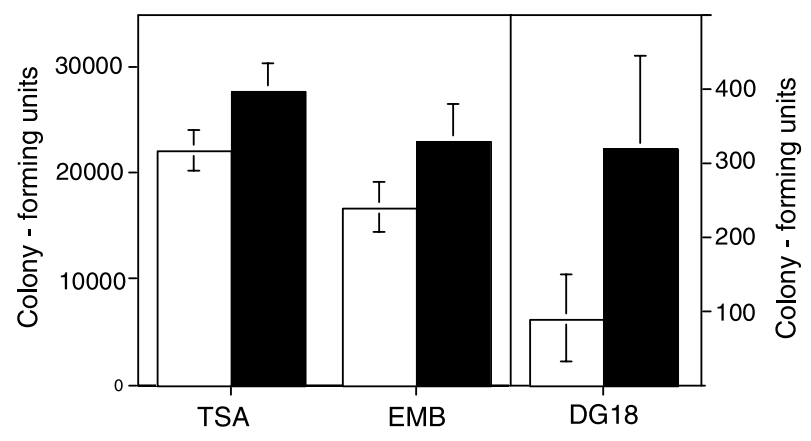

Figure 1 Mean ( $\pm \mathrm{SE}$ ) number of colony-forming units of bacteria and fungi per $10^{-4}$ gram of nest material, for nests containing resin (white bars) and resin-free nests (black bars). Tryptic Soy Agar (TSA) is a standard nutritive medium for bacteria, Eosin Methylene Blue agar (EMB) is specific for gram-negative bacteria, and Dichloran Glycerol (18) agar (DG18) is specific for xerophilic fungi.

Mann-Whitney $U$-test $U=77, P=0.019)$. Moreover, a marginally significant negative effect was detected for gramnegative bacteria (EMB: $23060 \pm 3470$ without resin and $16760 \pm 2590$ with resin, one-tailed Mann-Whitney $U$-test $U=71, P=0.056)$. Altogether, resin significantly inhibited microorganism growth (Fisher's combined probability test, $\chi^{2}=20.91$, d.f. $\left.=6, P<0.005\right)$. Three species of bacteria commonly found in samples of nest material from the field were identified: Pseudomonas luteola, Pseudomonas fluorescens and Aeromonas bydrophila. In order to test for a potential effect of resin on bacterial growth, $P$. luteola was isolated and cultivated on the TSA medium. $P$. luteola was clearly inhibited by the pieces of resin in vitro, with inhibition halos of $3.2-5.6 \mathrm{~mm}$ around both sterile and untreated pieces of resin.

\section{DISCUSSION}

We found that the wood ants Formica paralugubris incorporate variable but often large amounts of resin into their nests. For example, a large mound can contain as much as $20 \mathrm{~kg}$ of resin $\left(3 \mathrm{~m}^{3}\right.$ of nest material with $7 \mathrm{~g}$ of resin per litre). This finding is in accordance with early observations reporting the presence of large quantities of resin in wood ant mounds of various geographical areas (Donisthorpe 1915; de Réaumur 1928; Gösswald 1989). For example, in a Swedish sample, resin constituted from 1 to $44 \%$ of the dry weight of mounds (Lenoir et al. 1999).

Amounts of resin above the mean but within the range occurring in natural nests inhibited bacterial and fungal growth in experimental units. This effect was particularly pronounced for xerophilic fungi, with a three-fold decrease in the number of colony-forming units per gram of nest material. Altogether, the presence of resin had a significant 
negative impact on microorganism growth, as demonstrated when the probabilities from the three assays are combined using Fisher's method.

The three most frequent bacteria found in the present study are opportunistic pathogens in a variety of organisms (Freney et al. 1994; Jackson \& Phillips 1996; Picot et al. 2001). Of special relevance here, $P$. fluorescens is associated with septicaemia in another hymenopteran, the honeybee Apis mellifera (Schmid-Hempel 1998). The pronounced antifungal properties of resin may also be important against virulent entomopathogenic fungi such as Metarbizium and Beauveria (Schmid-Hempel 1998; Wilson et al. 2001). Together, the finding of common pathogenic bacteria in wood ant nests, the general inhibition of microorganisms by resin, and the specific inhibition of at least one potentially detrimental bacterium strongly suggest that bringing resin to the nest is an adaptive mechanism of defence against pathogens. However, further experimental studies will be needed to measure the costs and benefits associated with the use of resin, and to fully demonstrate the adaptiveness of this behaviour. In particular, it will be necessary to identify the specific pathogens that are inhibited by resin and to evaluate experimentally the effect of resin on infection dynamics, individual survival and colony productivity.

Our experiment demonstrates that the resin has antimicrobial effects in wood ant nests, in a context close to natural conditions. The antimicrobial activity detected here contrasts with previous work showing no negative impact of resin on fungal biomass when forest litter was incubated without ants (Lenoir et al. 1999). This difference highlights the fact that hypotheses of self-medication have to be tested in a natural context, and that experimental tests in vivo are needed (Clayton \& Wolfe 1993; Lozano 1998). A pharmacological effect of resin in natural conditions is understandable, because conifer resin contains a complex mixture of terpenes (Phillips \& Croteau 1999) with some antibacterial, antifungal and antiviral properties (Cowan 1999; Hodgson et al. 2002). For example, alpha-pinene and limonene, two major compounds of the oleoresin, are also abundant in terpenoid secretions of Nasutitermes termite soldiers, and reduce spore germination of the entomopathogenic fungus Metarbizium (Rosengaus et al. 2000). Microorganisms are probably inhibited by direct contact with resin as well as by volatile compounds passively diffusing into the nest atmosphere. Several species of birds and mammals also add plants with anti-parasitic effects to their nests (Clark \& Mason 1985; Lozano 1998; Hemmes et al. 2002; Petit et al. 2002). Hence, our experiment strongly suggests that wood ants take advantage of the plant defence. They collect and incorporate into their nests large amounts of a particular environmental resource that confers protection against microorganisms. Such a collective medication may play a crucial role in the extraordinary ecological success of insect societies, and may be an unrecognized yet common feature of large, complex and successful societies. Thus, honeybees collect a resinous compound that has many medicinal properties in vitro (Banskota et al. 2001) and leaf-cutting ants use antibiotic-producing bacteria to fight a parasitic fungus in their garden (Currie et al. 1999).

\section{ACKNOWLEDGEMENTS}

We thank Andrew F. Bourke, Jérôme Goudet, Rob Hammond, Laurent Keller, Anders P. Møller, Nicolas Perrin, Max Reuter, Paul Schmid-Hempel and four anonymous referees for comments on the manuscript. This work was supported by several grants from the Swiss National Science Foundation.

\section{REFERENCES}

Banskota, A.H., Tezuka, Y. \& Kadota, S. (2001). Recent progress in pharmacological research of propolis. Phytotherapy Res., 15, $561-571$.

Chapuisat, M. \& Keller, L. (1999). Extended family structure in the ant Formica paralugubris: the role of the breeding system. Behav. Ecol. Sociobiol., 46, 405-412.

Chapuisat, M., Goudet, J. \& Keller, L. (1997). Microsatellites reveal high population viscosity and limited dispersal in the ant Formica paralugubris. Evolution, 51, 475-482.

Clark, L. \& Mason, J.R. (1985). Use of nest material as insecticidal and anti-pathogenic agents by the European starling. Oecologia, 67, 169-176.

Clayton, D.H. \& Wolfe, N.D. (1993). The adaptive significance of self-medication. Trends Ecol. Evol., 8, 60-63.

Cowan, M.M. (1999). Plant products as antimicrobial agents. Clin. Microbiol. Rev., 12, 564-582.

Currie, C.R., Scott, J.A., Summerbell, R.C. \& Malloch, D. (1999). Fungus-growing ants use antibiotic-producing bacteria to control garden parasites. Nature, 398, 701-704.

de Réaumur, R.A.F., (1928). Histoire des Fourmis (written in 17421743). Paul Lechevallier, Paris.

Donisthorpe, H.S.J.K. (1915). British Ants, Their Life-History and Classification. William Brendon \& Son Ltd, Plymouth.

Freney, J., Renaud, F., Hansen, W. \& Bollet, C. (1994). Manuel de Bactériologie Clinique. 2nd edn. Elsevier, Paris.

Gösswald, K. (1989). Die Waldameise. Band 1. Biologische Grundlagen, Ökologie und Verbalten. Aula-Verlag, Wiesbaden.

Hart, A.G. \& Ratnieks, F.L.W. (2001). Task partitioning, division of labour and nest compartmentalisation collectively isolate hazardous waste in the leafcutting ant Atta cephalotes. Behav. Ecol. Sociobiol., 49, 387-392.

Hemmes, R.B., Alvarado, A. \& Hart, B.L. (2002). Use of California bay foliage by wood rats for possible fumigation of nest-borne ectoparasites. Behav. Ecol., 13, 381-385.

Hodgson, D.J., Vanbergen, A.J., Hartley, S.E., Hails, R.S. \& Cory, J.S. (2002). Differential selection of baculovirus genotypes mediated by different species of host food plant. Ecol. Lett., 5, 512-518.

Hölldobler, B. \& Wilson, E.O. (1990). The Ants. Springer-Verlag, Berlin. 
Hurst, C.J., Knudsen, G.R., McInerney, M.J., Stetzenbach, L.D. \& Walter, M.V. (1997). Manual of Environmental Microbiology. American Society for Microbiology. ASM Press, Washington.

Jackson, M.K. \& Phillips, S.N. (1996). Necrotizing hepatitis in pet birds associated with Pseudomonas fluorescens. Avian Dis., 40, 473476.

Lenoir, L., Bengtsson, J. \& Persson, T. (1999). Effects of coniferous resin on fungal biomass and mineralisation processes in wood ant nest materials. Biol. Fertil. Soils, 30, 251-257.

Lozano, G.A. (1998). Parasitic stress and self-medication in wild animals. Adv. Study Behav., 27, 291-317.

Møller, A.P., Dufva, R. \& Allander, K. (1993). Parasites and the evolution of host social-behavior. Adv. Study Behav., 22, 65102.

Moret, Y. \& Schmid-Hempel, P. (2000). Survival for immunity: The price of immune system activation for bumblebee workers. Science, 290, 1166-1168.

Nunn, C.L., Gittleman, J.L. \& Antonovics, J. (2000). Promiscuity and the primate immune system. Science, 290, 1168-1170.

Petit, C., Hossaert-McKey, M., Perret, P., Blondel, J. \& Lambrechts, M.M. (2002). Blue tits use selected plants and olfaction to maintain an aromatic environment for nestlings. Ecol. Lett., 5, 585-589.

Phillips, M.A. \& Croteau, R.B. (1999). Resin-based defenses in conifers. Trends Plant Sci., 4, 184-190.

Picot, L., Abdelmoula, S.M., Merieau, A., Leroux, P., Cazin, L., Orange, N. et al. (2001). Pseudomonas fluorescens as a potential pathogen: adherence to nerve cells. Microbes \& Infection, 3, 985 995.
Poulsen, M., Bot, A.N.M., Nielsen, M.G. \& Boomsma, J.J. (2002). Experimental evidence for the costs and hygienic significance of the antibiotic metapleural gland secretion in leaf-cutting ants. Behav. Ecol. Sociobiol., 52, 151-157.

Rosengaus, R.B., Lefebvre, M.L. \& Traniello, J.F.A. (2000). Inhibition of fungal spore germination by Nasutitermes: Evidence for a possible antiseptic role of soldier defensive secretions. J. Chem. Ecol., 26, 21-39.

Rosengaus, R.B., Maxmen, A.B., Coates, L.E. \& Traniello, J.F.A. (1998). Disease resistance: a benefit of sociality in the dampwood termite Zootermopsis angusticollis (Isoptera: Termopsidae). Behav. Ecol. Sociobiol., 44, 125-134.

Schmid-Hempel, P. (1998). Parasites in Social Insects. Princeton University Press, Princeton NJ.

Tella, J.L. (2002). The evolutionary transition to coloniality promotes higher blood parasitism in birds. J. Evol. Biol., 15, 32-41.

Traniello, J.F.A., Rosengaus, R.B. \& Savoie, K. (2002). The development of immunity in a social insect: evidence for the group facilitation of disease resistance. Proc. Natl. Acad. Sci., USA, 99, 6838-6842.

Wilson, K., Cotter, S.C., Reeson, A.F. \& Pell, J.K. (2001). Melanism and disease resistance in insects. Ecol. Lett., 4, 637-649.

Manuscript received 28 August 2002

First decision made 23 September 2002

Manuscript accepted 2 October 2002 